\title{
FLAVOUR OF PAPAYA (Carica papaya L.) FRUIT
}

\author{
C. HANNY WIJAYA ${ }^{1} *$ and FENG CHEN $^{2}$ \\ ${ }^{1}$ Department of Food Science and Technology, Faculty of Agricultural Technology \\ Bogor Agricultural University (IPB), Bogor 16680, Indonesia \\ ${ }^{2}$ Department of Food, Nutrition, and Packaging Sciences, Clemson University, \\ Clemson, SC 29634, USA
}

Received 28 August 2012/Accepted 18 December 2012

\begin{abstract}
Papaya is included in five major tropical fruits of the world after banana, mango, and pineapple. Indonesia is one of the leading countries of papaya production after India and Brazil. The Centre of Tropical Fruits Study (PKBT) at Bogor Agricultural University (IPB), Indonesia, has started a long- term breeding program since 2003 in order to improve the quality of local papayas. Fruit exports are being targeted at more specialized consumers, who are either seeking products either raised in more environmentally and health-conscious ways or those with a significant outstanding flavour. Flavour continues to be the predominant quality characteristic important for a successful international marketing. To understand the biosynthesis pathways are becoming more important for the flavour industry in recent years, as this could aid in the production of the flavour volatiles in the same manner as the natural biosynthesis. It is also necessary to understand the aroma active compounds and their changes during processing because unexpected changes in aroma may cause a product unmarketable even if other quality factors are acceptable. Understanding the changes of aroma active compounds in the papaya fruit, such as loss of desirable flavour and development of offflavour during processing will be very helpful for determining proper processing condition. The flavour composition of papaya fruit is reviewed in this paper. This paper presents an overview of important publications regarding the characteristic features of the biology of the fruits, consumption worldwide, commercial application in food processing, though the review of biogenesis of volatiles is still the main focus.
\end{abstract}

Key words: Papaya (Caricapapaya L.), flavour, review, volatiles, tropical fruit, biogenesis

\section{INTRODUCTION}

Excellent in vitamin C, pro-vitamin A, minerals (Wall 2006) as well as rich in dietary fibre, papaya (Carica papaya L.) is emerging as a popular fresh fruit which offers health benefiting properties. By the mid- $19^{\text {th }}$ century, papaya had spread over the tropical region, from Florida, Hawaii, India, Sri Lanka, Malaysia, Indonesia, to Africa (Morton \& MacLeod 1990).

* Corresponding author : hazemi@indo.net.id 
Wide variability is shown by papaya grown in various countries. Colour, texture, size, and particularly, flavour continue to be the predominant quality characteristics important for a successful international marketing of horticultural crops (Picha 2006). Fruit exports are being targeted at more specialized consumers, who are either those seeking products either raised in more environmentally and health-conscious ways or those who are prepared to pay a significant price for outstanding flavour (Zoe 2006).

There are a number of numerous literatures which discussed the volatiles present in the papaya fruits (Flath \& Forrey 1977; Idstein et al. 1985 ; Mohammed et al. 2001; Pino et al. 2003; Almora et al. 2004). Papaya possesses a characteristic aroma, which is due to several volatile components, such as alcohols, esters, aldehydes, and sulphur compounds (Marostica \& Pastore 2007). Like many other climacteric fruits, papaya undergoes a variety of physical and chemical changes after harvest (Shiota 1991). The biogenesis of flavours in fruits has been found to take place mostly during the ripening stage. The understanding of the biosynthesis pathways have been of increasing importance in the flavour industry in recent years, as this could aid in the production of the flavour volatiles in the same manner as the natural biosynthesis. This is crucial in allowing the flavours to be labelled as natural.

Pino et al. (2003) reported that based on more than 40 years of intensive research toward the volatile profiles of various papaya cultivars, almost 400 volatiles have been identified. The identified volatile profiles were various depending on the various methods used to extract and isolate the compounds and the species of the papaya used in the analysis (Pino et al. 2003; Devitt et al. 2006).

Furthermore, as mentioned before, the flavour of papaya fruit is a result of a complex interactions among sugars, organic acids, minerals, and aroma volatile compounds, which may vary with cultivar and production location. When the papaya fruits are subject to processing, there would be qualitative and quantitative alterations in the overall composition of volatile compounds (Mohammed et al. 2001). The processing of the papaya fruits involves the major structural changes in the fruit (e.g. slicing, pulping, heating and freezing) that can result in a significant change in the sensory characteristics.

It is also necessary and crucial to understand the aroma active compounds and their changes during processing because unexpected/unpleasant changes in aroma may make a product unmarketable even if the other quality factors are acceptable. Therefore, understanding the changes of aroma active compounds in the papaya fruit, such as loss of desirable flavour and development of off-flavour during processing will be very helpful for determining proper processing condition.

In this paper, the flavour composition of papaya fruit is reviewed. However, the information is not limited to a compilation of reported volatile compounds. This review will also present an overview of important publications and a description of the characteristic features of the biology of the fruits, consumption worldwide, commercial application in food processing, though review of volatile compounds will still be the main focus which that includes two aspects, i.e., the analytical methodology used for the determination of the volatile compounds and the contribution of individual components to the characteristic flavour. Future researches will be also highlighted. 


\section{BIOLOGY AND WORLDWIDE CONSUMPTION}

The papaya, Caricapapaya L., is a member of the small family Caricaceae with genus Carica and species Carica papaya L. According to its taxonomy classification, papaya is under the superkingdom Eukaryota, kingdom Virdiplantae, phylum Streptophyta, sub phylum Embryophyta, division Tracheophyta, sub division Spermatophyta, super class magnoliophyta, class Rosidae, order Brassicales, and the family Caricaceae (TRACE 2012; Paull \& Duarte 2011). However, a recent taxonomic revision proposed that some species formerly assigned to Carica were more appropriately classified in the genus Vasconcella (Badillo 2002).

Papaya is a fast growing tree like herb that can grow at the rate of 6 to $10 \mathrm{ft}(1.8-3 \mathrm{~m})$ in the first year and reaching 20 or even $30 \mathrm{ft}(6-9 \mathrm{~m})$ in height, with a hollow green or deep-purple stem becoming 12 to 16 inch $(30-40 \mathrm{~cm})$ or more thick at the base and roughened by leave scars. The leaves emerge directly from the upper parts of the stem in a spiral on nearly horizontal petioles 1 to $3 \frac{1}{2} \mathrm{ft}(30-105 \mathrm{~cm})$ long, hollow, succulent, green or more less dark purple. The blade, deeply divided into 5 to 9 main segments, each irregularly subdivided, varies from 1 to $2 \mathrm{ft}(30-60 \mathrm{~cm})$ in width and has prominent yellowish ribs and vein. The life of a leaf is 4 to 6 months. Both the stem and leaves contain copious white milky latex (Morton 1987).

The five-petal led flowers are fleshy, waxy and slightly fragrant. Papaya flowers are born on inflorescences which appear in the axils of the leaves. Female flowers are held close against the stem as single flowers or in clusters of 2-3 (Chay-Prove et al. 2000). Male flowers are smaller and more numerous and are born on $60-90 \mathrm{~cm}$ long pendulous inflorescences (Nakasone \& Paull 1998). Bisexual flowers (hermaphrodite) are intermediate between the two unisexual forms (Nakasone \& Paull 1998). The functional gender of flowers can be altered or reversed, depending on environmental conditions, particularly temperature. Some trees bear only short-stalked female flowers or bisexual (perfect) flowers also on short stalks, while other may bear only male flowers, clustered on panicles 5 or $6 \mathrm{ft}$ long. Some trees have both male and female flowers. At certain seasons the trees produce short-stalked male flowers, while at other times perfect flowers. Certain varieties have a propensity for producing certain types of flowers. Male or bisexual trees may change completely to female trees after being beheaded. Only hermaphrodite (bisexual flowered) papaya tree can bear fruit in a single tree by self-pollinating. The female papaya tree can also produce fruit from cross pollination by either bisexual or male trees. Although male tree may sometimes bear fruit, it is not edible (FAO 1992). The fruit is melon-like with an oblong or elliptic shape. Fruits from female trees are spherical, whereas the shape of fruit from bisexual trees is affected by environmental factors, particularly temperature that modifies floral morphology during early development of the inflorescence (Nakasone \& Paull 1998). Fruits are ready to be harvested five to six months after flowering, which occurs five to eight months after seed germination (Chay-Prove et al. 2000).

Ripe papaya fruits have smoothed, thin green-yellow-orange coloured skin. Depending on the cultivar, flesh thickness varies from 1.5 to $4 \mathrm{~cm}$ (Nakasone \& Paull 1998) and flesh colour may be pale yellowish-orange to red (Villegas 1991; Nakasone 
\& Paull 1998). The central cavity of mature fruits is containing numerous grey-black spherical seeds of $5 \mathrm{~mm}$ in diameter (Villegas 1991). The fruits range in size from 7-30 $\mathrm{cm}$ long and vary in mass from about 250 to $3000 \mathrm{~g}$ (OECD 2003).

According to Rivera (2005), papaya varieties generally can be divided into two groups, the small fruits weighing 500 grams below and big fruits weighing from $500 \mathrm{~g}$ up to $10 \mathrm{k}$. Whereas, Cosidine and Cosidine (1982) divided papaya into four categories according to its size, i.e., small size weighing $0.3-.4 \mathrm{~kg}$, medium size weighing 0.4-0.45 $\mathrm{kg}$, big size weighing $0.45-0.9 \mathrm{~kg}$, and very big size weighing more than $0.9 \mathrm{~kg}$.

In order to improve the quality of local papayas, the Centre of Tropical Fruits Study (PKBT) at Bogor Agricultural University (IPB), Indonesia, has started a longterm breeding program since 2003. This program targets at developing new cultivars which will have outstanding specifications and characteristics that will be desirable for international market demand, resistant to biotic and abiotic stress and have high yield (Anonymous 2003).

Until 2005, the program has screened 75 genotypes of papaya collected from several areas in Indonesia and those introduced from abroad. This papaya genetic bank collection has been divided into two categories based on size: small papaya and medium-big papaya, or on its specific utilization purpose as vegetable/fruit papaya or papain produced papaya (Anonymous 2005). Among the 24 genotypes that have been morphologically characterized, 'Eksotika', 'Sunrise Solo', 'Bangkok', 'Red King' and 'California' were recommended by PKBT as outstanding varieties of vegetable/fruit papaya. There are also other three outstanding genotypes obtained from open pollinated breeding released by PKBT named 'Papaya Arum Bogor' (small-type), 'Papaya Prima Bogor (medium-type) and 'Papaya Wulung Bogor (papain producer). Some other superior genotype candidates such as IPB 3, IPB 8, IPB 6, IPB 9 are still under evaluation (Anonymous 2005; Sriani 2008-personal communication).

Healthy, low in calories and a rich source of vitamins, calcium and phosphorous, the papaya is one of the most easily digested fruits. The ripe papaya fruit is consumed as fresh table fruit. Sometimes it is cut in wedges and served with lime or lemon juice, also in few cases, a few seeds (just a few) are left attached to a peppery flavour. The firm-ripe flesh is often cubed or shaped into balls and served in fruit salad or fruit cup as well as seasoned and baked for consumption (Morton 1987). However, in many Asian countries, especially Japan, Malaysia, Vietnam, Indonesia and Thailand, the fruit is consumed as grated vegetable while still in the green stage. Papaya cuisine is now becoming popular in European society.

There is also an array of processed papaya products available prepared by minimal processing, drying, canning, pickling and freezing. Ripe flesh is commonly made into sauce for shortcake or ice-cream sundaes, or is added to ice cream just before freezing. It can also be cooked as pie, pickled, or preserved as marmalade or jam, papaya cubes with other fruits, covered with sugar syrup, may be quick-frozen for later serving as dessert. Papaya juice and nectar may be prepared from the fruit and are sold fresh in bottled or canned. Half-ripe fruits are sliced and crystallized as a sweetmeat (Morton 1987). Green papaya puree can also be utilized as chilly-sauce thickener.

Young leaves of papaya can be cooked and eaten as vegetables in several countries in Asia. Papaya leaves contain the bitter alkaloids, carpaine and pseudeocarpaine, 
which can be destroyed by heat. Sprays of male flowers are sold in Asian including Indonesian and New Guinea markets after being boiled with several changes of water to remove the bitterness and eaten as a vegetable. In Africa, the young stems are cooked and served. Papaya seeds are sometimes found as an adulterant of whole black pepper (Morton 1987).

According to Philippine Council for Agricultural, Forestry and Natural Resources Research and Development (PCARRD-DOST 2004), papaya is grouped in five major tropical fruits after banana, mango, pineapple which shared 6 percent of on estimated world production of tropical fruits in 2004. Evans and Ballen (2012) reported that based on FAO statistical division data 2012, the global papaya production in 2010 was estimated 11.22 metric tons or 15.36 percent of the total tropical fruit production, ranked third. However, other sources said that it is impossible to obtain reliable estimates of total world papaya production, since the home-grown crops are unregistered. This phenomenon clearly occurs in Indonesia, although it is believed that the annual production must be several million metric tons. The leading global papaya producing countries for period 2002-2010 were India (36.6\%), followed by Brazil (17.5\%) and Indonesia (6.9\%). While Sidhu (2006) reported the leading country of papaya production is Brazil, followed by Nigeria, India, Mexico and Indonesia.

According to the National Agricultural Statistics Service (NASS 2007), only Hawaii in the United States produces 45.9 million pounds of papaya fruit on about 2,320 acres in 2002 , however, the production is declining every year. The production was only 28.7 million pounds on about 2,095 acres in year 2006 (NASS 2007). Most of the papaya grown in Hawaii is consumed as fresh fruit (93\%), only small amounts were processed into juices or other processed foods.

\section{FLAVOR IN PAPAYA (CARICA PAPAYA)}

\section{Methods of extraction, isolation and identification of papaya aroma compounds}

The determination of aroma substances by instrumental technique generally consists of two stages. The first phase is the isolation of analytes from the complicated food matrix based on two primary principles-volatility and/or solubility. The second phase is the identification of the analytes. It is essential to isolate the desired volatile compounds in order to eliminate interfering signals coming from the complex food matrix. Hence, it is important to select an appropriate sample preparation method so that the isolated product can be possibly representative. Currently, there are many isolation techniques that can be used depending on the properties of the food product.

Generally, there are two common extraction techniques used in extracting volatile compounds from papaya, namely the simultaneous distillation/solvent extraction (SDE) (Macleod \& Pieris 1983; Morales \& Duque 1987; Almora et al. 2004) and the dynamic headspace analysis (Mohammed et al. 2001; Flath et al. 1990). These two 
methods are also commonly used for the study of volatiles compounds of other fruits such as apples (Argenta et al. 2004; Shashirekha et al. 2008), mangoes (Sakho et al. 1998; Torres et al. 2007), mangosteens (Macleod \& Pieris 1982), peaches and nectarines (Lavilla et al. 2002).

The principal of SDE technique is based on the differences in volatility and polarities among the analytes and other non-volatile components present in the food matrix (Teixeira et al. 2007). An appropriate solvent also should be chosen to facilitate the extraction of the important volatile components, while excluding/limiting the components that could interfere with the analysis. In SDE method, the sample is simultaneously distilled and extracted from steam condensate by organic solvents reflux, such as diethyl ether (Almora et al. 2004) and $\mathrm{CH}_{2} \mathrm{Cl}_{2}$ (Morales \&Duque 1987) in a Likens and Nickerson apparatus. The concentrated extracts will then be analyzed by GCO and/or GC-MS. The advantages of SDE analysis of volatile compounds are obvious that only two single main operations (extraction and concentration) are required and yet give a relatively wide spectrum of chemical compounds detected (Peng et al. 2004), and due to the continuous recycling, a relatively small quantity of organic solvent is used. In addition, it minimizes the possibility of artefact introduction from this source (Schultz et al. 1977).

Dynamic headspace technique uses a "purge and trap" method involving the passing of carrier gas through a liquid sample, followed by trapping of the volatile analytes on an absorbent material, and the analytes are flushed onto the column for analysis by GC or GC-MS (Snow 2002). Mohammed et al. (2001) had collected the volatiles by using Tenax as the absorber, and used purified nitrogen gas to flush sample onto the Tenax trap. The aliquots collected were then injected into GC-MS.

Recent study on the papaya volatiles has been reported by Ulrich and Wijaya (2010). Two different sample preparation methods which are liquid-liquid extraction and stir bar sorptive extraction (SBSE) have been utilized in the analysis. There were clear different results obtained using these two methods. It has been known that the utilization of SBSE as well as Solid Phase Microextraction (SPME), although they are more rapid isolation compared to liquid-liquid or SDE, only strong substances will be discriminated. The sample preparation using SBSE is effective and usable in the aroma comparison research topic. However, it is not a proper approach for aroma identification since it will not cover all character impact compounds responsible for the wholesome aroma of the sample.

Generally, selecting different extraction techniques might lead to the identification of different volatile compounds. This could be due to inadequate sensitivity (i.e., only the most abundant volatiles can be detected and/or unable to detect trace compounds) and different in selectivity of the trap or solvent used (i.e., non-polar compounds can hardly be extracted by polar solvents/trap absorbent). For instance, Larrayoz et al. (2001) reported that the dynamic headspace technique combined with a purge \& trap device could extract more highly volatile compounds than the SDE method. In contrast, the SDE is more efficient for extracting low-volatile components such as phenols, free fatty acids, lactones and longer-chain aldehydes, ketones, alcohols and esters. 
BIOTROPIA Vol. 20 No. 1, 2013

Table 1: Aroma active compounds as reported by different researchers found in papaya

\begin{tabular}{|c|c|c|c|c|c|c|}
\hline $\begin{array}{c}\text { Aroma } \\
\text { active } \\
\text { compound }\end{array}$ & Synonym (s) & $\begin{array}{c}\text { Odor } \\
\text { Descriptors }\end{array}$ & Molecular & $\begin{array}{c}\mathrm{Mr} \\
(\mathrm{g} / \mathrm{mol})\end{array}$ & $\begin{array}{l}\text { B.P. } \\
\left({ }^{\circ} \mathrm{C}\right)\end{array}$ & CAS registry no. \\
\hline $\begin{array}{l}\text { Butanoic } \\
\text { acid }\end{array}$ & $\begin{array}{l}\text { Butyric acid, octyl } \\
\text { butyrate }\end{array}$ & $\begin{array}{l}\text { Pungent } \\
\text { unpleasant } \\
\text { odor, } \\
\text { acrid-taste }\end{array}$ & $\mathrm{C}_{4} \mathrm{H}_{8} \mathrm{O}_{2}$ & 88.106 & 163.5 & $107-92-6$ \\
\hline $\begin{array}{l}\text { 4-Methyl- } \\
\text { octane }\end{array}$ & 4-Methyloctane & $\begin{array}{l}\text { Somewhat } \\
\text { pungent, } \\
\text { citrus-like }\end{array}$ & $\mathrm{C}_{9} \mathrm{H}_{20}$ & 128.255 & 142.4 & $2216-34-4$ \\
\hline $\begin{array}{l}\text { Hexanoic } \\
\text { acid }\end{array}$ & $\begin{array}{l}\text { Caproic acid; pentane } \\
\text { 1- carboxylic acid; } \\
\text { hexylic acid; } \\
\text { hexoic acid }\end{array}$ & $\begin{array}{l}\text { Strong fruity } \\
\text { odor, } \\
\text { pineapple- } \\
\text { like }\end{array}$ & $\mathrm{C}_{6} \mathrm{H}_{12} \mathrm{O}_{2}$ & 116.16 & 205 & $142-62-1$ \\
\hline $\begin{array}{l}\text { Benzene- } \\
\text { methanol }\end{array}$ & $\begin{array}{l}\text { Phenyl carbinol; } \\
\text { alpha- } \\
\text { hyroxytoluene; } \\
\text { benzoly alcohol; } \\
\text { phenyl methanol }\end{array}$ & $\begin{array}{l}\text { Mild-sweet } \\
\text { aroma like }\end{array}$ & $\begin{array}{l}\mathrm{C}_{7} \mathrm{H}_{8} \mathrm{O} / \\
\mathrm{C}_{6} \mathrm{H}_{5} \mathrm{CH}_{2} \mathrm{O} \\
\mathrm{H}\end{array}$ & 108.1 & 205 & $100-51-6$ \\
\hline $\begin{array}{l}\text { Trans- } \\
\text { linalool } \\
\text { oxide } \\
\text { (furanoid) }\end{array}$ & $\begin{array}{l}\text { (2R,5R)-5 isopropyl- } \\
2 \text {-methyl-2- } \\
\text { vinyltetrahydro- } \\
\text { furan }\end{array}$ & Earthy-leafy & $\mathrm{C} 10 \mathrm{H} 18 \mathrm{O} 2$ & 170.2487 & $\begin{array}{l}222.6^{\circ} \mathrm{C} \text { at } \\
760 \mathrm{mmHg}\end{array}$ & $34995-77-2$ \\
\hline $\begin{array}{l}\text { Cis- } \\
\text { linalool } \\
\text { oxide } \\
\text { (furanoid) }\end{array}$ & $\begin{array}{l}\text { (2R,5R)-5 isopropyl- } \\
2 \text {-methyl-2- } \\
\text { vinyltetrahydro- } \\
\text { furan }\end{array}$ & $\begin{array}{l}\text { Sweet, } \\
\text { floral,creamy, } \\
\text { fruity }\end{array}$ & $\mathrm{C} 10 \mathrm{H} 18 \mathrm{O} 2$ & 170.2487 & $\mathrm{NA}$ & $60047-17-8$ \\
\hline $\begin{array}{l}\text { Benzyl- } \\
\text { acetate }\end{array}$ & $\begin{array}{l}\text { Acetic Acid Benzyl } \\
\text { Ester; } \\
\text { Acetic acid } \\
\text { phenylmethyl ester; } \\
\text { alpha- } \\
\text { acetoxytoluene; } \\
\text { Benzyl Ethanoate; } \\
\text { Phenylmethyl } \\
\text { Acetate }\end{array}$ & $\begin{array}{l}\text { Fruity, apple } \\
\text { and pear-like }\end{array}$ & $\begin{array}{l}\mathrm{CH}_{3} \mathrm{COOC} \\
\mathrm{H}_{2} \mathrm{C}_{6} \mathrm{H}_{5}\end{array}$ & 150.18 & 215 & $140-11-4$ \\
\hline $\begin{array}{l}\text { Linalool } \\
\text { cis- } \\
\text { pyranic } \\
\text { oxide } \\
\end{array}$ & NA & Citrus-like & $\mathrm{C} 15 \mathrm{H} 24 \mathrm{O} 3$ & 252.3493 & $\begin{array}{l}356.1^{\circ} \mathrm{C} \text { at } \\
760 \mathrm{mmHg}\end{array}$ & 14009-71-3 \\
\hline $\begin{array}{l}\text { Cyclo- } \\
\text { hexane }\end{array}$ & $\begin{array}{l}\text { Hexamethylene; } \\
\text { Hexanaphthene; } \\
\text { hexahydro-benzene; } \\
\text { benzenehexahydride; }\end{array}$ & Sweet-fruity & $\mathrm{C}_{6} \mathrm{H}_{12}$ & 84.16 & 80.7 & $\begin{array}{l}\text { 695-06-7;57129-70- } \\
1( \pm)-\text { form; 63357- } \\
95-9(\mathrm{R}) \text {-form } \\
41035-07-8(S) \\
\text { form: }(\AA) \text {-form }\end{array}$ \\
\hline $\begin{array}{l}\text { Gamma- } \\
\text { hexalactone }\end{array}$ & $\begin{array}{l}\text { 4-hexanolactone; } \\
\text { 4-Caprolactone; } \\
\text { 4-ethyl } \\
\text { butrolactone;4- } \\
\text { hydroxyhexanoic } \\
\text { acid lactone;4- } \\
\text { hexanolide }\end{array}$ & $\begin{array}{l}\text { Sweet, } \\
\text { creamy, } \\
\text { lactonoic, } \\
\text { fruity, } \\
\text { coumarin-like } \\
\text { with green } \\
\text { coconut } \\
\text { nuances } \\
\end{array}$ & $\mathrm{C}_{6} \mathrm{H}_{10} \mathrm{O}_{2}$ & 114.44 & 216 & \\
\hline $\begin{array}{l}\text { Gamma- } \\
\text { octalctone }\end{array}$ & $\begin{array}{l}\text { 5-butyldihydroxy } \\
-2(3 \mathrm{H})- \\
\text { furanone;4- } \\
\text { octanolide;4- } \\
\text { buthy- } \text { - } \\
\text { butyrolactone }\end{array}$ & $\begin{array}{l}\text { Coconut-like } \\
\text { odor, sweet, } \\
\text { lactonoic, } \\
\text { fruity creamy, } \\
\text { coumarin }\end{array}$ & $\mathrm{C}_{8} \mathrm{H}_{14} \mathrm{O}_{2}$ & 142.197 & 117 & $\begin{array}{l}108943-45-9(\mathrm{R}) \\
\text { form }\end{array}$ \\
\hline \multirow[t]{3}{*}{$\begin{array}{l}\text { Delta- } \\
\text { octalactone }\end{array}$} & \multirow{3}{*}{$\begin{array}{l}\text { 5-octanolide;5- } \\
\text { hydroxyoctanoic } \\
\text { acid lactone }\end{array}$} & \multirow{3}{*}{$\begin{array}{l}\text { Sweet, } \\
\text { creamy, fatty } \\
\text { with tropical } \\
\text { and dairy } \\
\text { nuances, } \\
\text { fruity }\end{array}$} & \multirow[t]{3}{*}{$\mathrm{C}_{8} \mathrm{H}_{14} \mathrm{O}_{3}$} & \multirow[t]{3}{*}{142.197} & 140 & $\begin{array}{l}108943-46-0(\mathrm{~S}) \\
\text { form }\end{array}$ \\
\hline & & & & & 80 & $\begin{array}{l}104426-32-6( \pm) \\
\text { form }\end{array}$ \\
\hline & & & & & 126 & \\
\hline
\end{tabular}


Approximately 150-200 volatile components of ripe papaya pulp have been reported in various papers (Flath \& Forrey 1977; MacLeod \& Pieris 1983; Idstein \& Schreier 1985; Schreier et al. 1985). These volatiles are released by harvested intact fruit in small amount per unit time, and some of the reported volatile compounds are only generated in quantity from non-volatile precursors due to the disruption of fruit tissue (Flath et al. 1990). Volatile constituents from papaya extracted by both the simultaneous distillation/solvent extraction method and dynamic headspace analysis are listed in Table 1.

Volatiles identified in these studies included heterocyclic compounds, terpenoids, aromatic hydrocarbon, alcohol, acids, esters and ketones. A fairly wide range of different types of compounds have been identified in different studies (as shown in Table 1), partly due to papaya species aside from the type of extraction and analysis technique used. For instance, the volatiles of Sri Lanka papaya were dominated by esters (MacLeod \& Pieris 1983), whereas terpenoids (mainly linalool and linalool oxides) provided the most abundant group of volatiles for Hawaiian papaya (Flath \& Forrrey 1977).

On the other hand, different method approaches might be able to show the same tendencies. For instance, the volatile components of papaya (Solo variety) which were recovered by four different methods: e.g., vacuum trapping train (distillation under low temperatures with liquid nitrogen traps), co-distillation-extraction (vacuum), distillation, and co-distillation-extraction (1 atm.), showed that, in spite of great variations due to the recover method, linalool was always the major compound detected in all the methods (Flath \& Forrey 1977).

Mohammed et al. (2001) had identified a total of 26 aroma volatiles emanating from fresh cut papaya (Carica papaya L. cv. Solo) using the dynamic headspace technique followed by GC-MS, where some had not been reported by Schreier and Winterhalter (1986). However, some of these newly identified volatiles such as 4methyl-1-octane, tetrahydro-3-furfuryl-furan and 2,4-dimethylhexane may have arisen due to the mechanical damage sustained by the tissue during preparation (Mohammed et al. 2001). In addition, 11 out of these 26 aroma volatiles were identified as aroma active compounds, namely, butanoic acid, 4-methyloctane, hexanoic acid, benzenemethanol, trans-linalool oxide, linalool, benzyl acetate, linalool cis-pyranic oxide, cyclohexane and benzaldehyde. It was also shown in the study that the volatile extract obtained from papaya slices changed from a distinct fresh sweet and flowery odour to slightly less evident, then to an unpleasantly dry, pungent and fruity odour which could be explained by the changes in the distribution of these aroma active compounds during storage. This in turn illustrated the aroma of papaya due to a complex and dynamic integration of compounds which changed with time as well.

\section{Aroma-active compounds of papaya}

Papaya is a climacteric fruit that undergoes the ripening process upon harvesting, until the stage where a fully ripened papaya gives fully developed flavours and odours which then perceived and recognized by human as an indication that the papaya is ripened. Hence, the papaya fruit gives its characteristic fruity, balsamic, sweet odours 
after undergoing a variety of physical and chemical changes during the ripening process. Herein, aroma components that give the aroma characteristic of a food are called aroma active compounds or character impact compounds.

Mohammed et al. (2001) reported that the dominating aroma-active compounds in papaya were linalool and benzaldehyde. This claim is also supported by Chan et al. (1973) who reported that the major odorous compounds from fresh, ripened papaya (Carica papaya) were linalool, with smaller amount of ethyl acetate, 1-butanol, two configurational isomers of the linalool oxides (2-methy-2-vinyl-2-(hydroxyl-2-propyl) tetrahydrofuran), and benzyl isothiocyanate. Also, gamma-hexalactone, gamma octalactones and delta octalactones were reported in other literatures (Sidhu, 2006) as aroma-active compounds contributing to the overall perceived characteristic aroma of the papaya.

Other prominent volatiles like butanol, 3-methylbutnol, benzyl alcohol and aterpineol in papaya (Carica papaya L., Maradol roja) at its mature stage were also reported by Almora et al. (2004), who also mentioned a decrease in benzyl isothiocyante, and increase in linalool, terpinen-4-ol, esters (methyl butonoate, ethyl hexanoate and ethyl dodecanoate). The combination of the different esters is associated with the detected fruity note (Arctander 1969), whilst balsamic note could be attributed to benzyl alcohol and $\alpha$-terpineol concentrations during ripening (Almora et al. 2004). The major aroma-active compounds present in cut papaya was identified to be linalool, benzaldehyde and benzyl isothiocyanite (BITC).

Linalool is the most dominant aroma-active compound present in the papaya (Carica papaya L.). The chemical name is 3,7-dimethyl-1,6-octdine-3-ol. ( \pm )-Linalool (22564-99-4), like the individual enantiomers, a colourless liquid. It is an acylic terpene with a flowery and fresh odour reminiscent of lily of the valley (Bauer et al. 1997). However, the enantiomers differ slightly in odour (Klein \& Ohloff 1962). The aroma threshold for linalool was found to be within 4 to $10 \mathrm{ppb}$. At $30 \mathrm{ppm}$, it has a taste characteristic of floral, woody, and sweet, with a green spicy tropical nuance. Hence, the presence of linalool at different concentrations in a wide range of foods might give a slightly different characteristic sweet-flowery aroma in the foods. In the presence of acids, linalool isomerizes readily to geraniol, nerol and $\alpha$ - terpineol. It is oxidized to citral by chromic acid. Oxidation with peracetic acid gives linalool oxides, whilst hydrogenation of linalool yields tetrahydrolinalool, which is often used as a fragrance compound. Also, linalool can be converted into linalyl acetate by reacting with ketone or excess of boiling acetic anhydride.

Benzaldehyde is also the dominating aroma-active compound in papaya, having a characteristic of bitter almond oil and imparting a bitter-nutty and almond odour (Mohammed et al. 2001). It is also named benzene carboxaldehyde and almond artificial essential oil. Benzaldehyde undergoes auto-oxidation in the absence of inhibitors to perbenzoic acid, which then react with a second molecule of benzaldehyde to benzoic acid. Upon hydrogenation of benzaldehyde, benzyl alcohol will be formed.

Benzyl isothiocyanate (BITC) is found in enzymic hydrolysates of extracts from various plant families: namely, Cruciferae, Moringaceae, Capparidaceae, Tropaeolacea, Caricaceae, Gyrostemonaceae and Salvadoraceae (Ettlinger \& Hodgkins 1956; Ettlinger \& 
Kjaer 1968), or can be synthesized in bruised or injured papaya. It possesses pungent, off-flavour aroma. As revealed by Tang (1971), benzyl isothiocyanate is a natural metabolite emanating from intact green papaya. Also, he mentioned that the concentration of benzyl isothiocyanate (or its glucosinolate precursor) decreased in the flesh of papaya whilst it increased in the seeds with maturity. Despite the decreasing concentration of BITC along with maturation, it can make significant sensory impression since it has a very obnoxious nature of low threshold.

On top of the elaborated aroma-active compounds, other aroma active compounds that are present in smaller amounts (shown in Table 1) also contribute to the overall perceived aroma of ripe papaya. Hence, each individual aroma active compounds has its own vital role in giving our sensory a full picture on the papaya aroma.

In another investigation, linalool was detected in relatively low concentration in the solvent-extracted volatiles of fresh papaya pulp from Sri Lanka, while esters represented the majority. The authors attributed the characteristic sweaty note of this papaya fruit mainly to methyl butanoate. Phenylacetonitrile was also found in high amounts $(17.7 \%)$ combined with lower concentration of benzyl isothiocyanate $(1.5 \%)$, which played a critical role in the aroma of papaya (MacLeod \& Pieris 1983).

Oxygenated terpenoids derived from linalool might play an important role in Brazilian papaya aroma. Several oxygenated derivatives of linalool were identified in the solvent-extracted samples, such as the two diasteroisomers of 6,7epoxylinalool:2,6-dimethyl-octa-1,7-diene-3,6-diol and 2,6-dimethyl-octa-3,7-diene2,6,-diol (Winterhalter 1986).

Fifty-one volatile components from intact Hawaiian papayas of different ripeness were recovered by Tenax using the "trap and purge" method. As expected, the largest number of components was found in the fully ripe fruits. Linalool, followed by linalool oxide $\mathrm{A}$, linalool oxide $\mathrm{B}$, and ethyl acetate were the major components in the fully ripe fruits. It is worth noting that several compounds, e.g., linalool and all aldehydes, exist in all four ripeness stages (Flath et al. 1990).

Another investigation reported the esters as the predominant volatile components of the Maradol variety (about $41 \% \mathrm{w} / \mathrm{w}$ of the total volatiles) (Pino et al. 2003). The major representative compounds in the simultaneous steam distillationsolvent extraction were methyl butanoate and ethyl butanoate. Previous work described the esters as the predominant compounds among the volatiles; papaya, for example from Sri Lanka and Colombia had 52 and $63 \%$ of esters in the total volatiles, respectively (MacLeod \& Pieris 1983; Morales \& Duque 1987).

Studies on the diversity of papaya volatiles in different cultivars and new breeding lines have been conducted by Ulrich and Wijaya (2010). Character impact compounds such as hexanal, cis-2-pentenol, nonanal, cis-linalool oxide, linalool, butanoic acid, verbenone, phenyl methyl of butanoic acid and others have been detected. The volatiles patterns differ significantly among the genotypes resulting in very different sensory quality. The gained obtained knowledge will contribute to the breeders' ability in developing new papaya varieties with acceptable flavour properties (Ulrich \& Wijaya 2010). 
Despite the significant diversity in aroma compounds of papaya fruit, the volatiles in papaya are mainly derived from three major metabolism pathways: the catabolism of fatty acid, amino acid, and carbohydrates. The biosynthesis pathways are usually interlinked, with products from one pathway serving as the precursors for another pathway. These degradation reactions account for many aroma compounds, as they result in the formation of a host of low molecular weight products which has significant sensory properties. This catabolism is associated with fruit ripening, during the climacteric rise in respiration, and the rate of flavour formation reaches a maximum during the post-climacteric ripening phase (Reineccius 2006). The metabolism pathways will be elaborated in the following sections.

\section{Papaya Flavour Biogenesis}

Aroma compounds may be formed from lipids via several different pathways. The primary pathways involved in the aroma of papaya include the enzymatic conversion of acyl lipids through ßoxidation and oxylipin/lipoxygenase pathways (Reineccius, 2006). These pathways generate short branched-chain aldehydes, alcohol, ester and ketones. Fatty acid derived volatiles play important regulatory roles in defence and plant development. Fatty acid volatiles are formed in intact fruit via the Boxidation pathway while cut or damaged tissues can form volatiles via the oxylipin biosynthesis pathways (Devitt et al. 2006). In papaya, methyl and ethyl ester derivates of lipid catabolism have been identified as strong contributors to aroma (MacLeod \& Pieris 1983; Morales \& Duque 1987), examples include ethyl butyrate, ethyl acetate, methyl butyl acetate, ethy butanoate and methyl butanoate. Significant amount of butanol has also been reported (Morales \& Duque 1987).

In the papaya plant, $\beta$-oxidation occurs in the peroxisomes, organelles which contain enormous amounts of enzymes. The substrate of the reaction is an acyl. The acyl lipid reacts with two CoA molecules, one ATP, one FAD, one water molecule, and one NAD to form an acetyl CoA molecule and an acyl CoA molecule. Using acetyl CoA as precursor, several other compounds such as esters, sterols, and most terpenes can be synthesized (Reineccius 2006). The acetyl CoA molecule can also undergo reaction to reform into fatty acid such as butyric acid which contributes to the papaya aroma.

As mentioned above, the biogenesis of certain volatiles in papaya can be further explained by a process known as the oxylipin pathway, which in brief, is the metabolism of polyunsaturated fatty acids (PUFAs) by lipoxygenase (linoleate oxygen oxidoreductase; LOX) and the subsequent reactions after it. Stumpe et al. (2005) and Chehab et al. (2007) reported that: "This pathway is initiated by the action of lipases on complex membrane lipids in the fruit, causing the release of unesterified fatty acids. The free polyunsaturated fatty acids which contain a (cis, cis)-1,4-pentadiene structure then act as substrates for the enzyme LOX introducing molecular oxygen to them to form their corresponding hydroperoxy derivatives. These derivatives then undergo further enzymatic reactions to give rise to fatty acid hydroperoxides, hydroxyl fatty acids, epoxy fatty acids, keto fatty acids, volatile aldehydes and cyclic compounds, which are collectively known as oxylipins. Some of these products are responsible for the unique aroma of the papaya fruit. 
Unstable allene oxides are formed from the activity of allene oxide cyclase (AOS). They can either undergo nonenzymatic hydrolysis leading to alpha-and gamma-ketols, or be metabolized to 12-Oxophytodienoic acid (OPDA) by AOC. Subsequently, OPDA is transported to the peroxisomes where its cyclopentenone ring is reduced by OPDA reductase to form OPC:8. Finally, the OPC:8 is subjected to three rounds of beta-oxidation to yield jasmonic acid (JA) (Chehab et al. 2007). JA and its precursor OPDA are signalling compounds that play a role in plant development and response to injury (Stumpe et al. 2005). JA is also converted to a variety of derivatives like its ester, methyl jasmonate, which contributes to the aroma of the papaya fruit.

The other major metabolic route that is dominant for the direct production of important compounds of the characteristic aromas of many fruits including papaya is hydroperoxide lyase (HPL) pathway (Yilmaz 2001). HPL catalyzes the oxidative cleavage of fatty acid hydroperoxides, producing volatile aldehydes and oxoacids. The HPL enzyme can yield C-6 aldehydes and C-12 omega-oxoacids from the 13hydroperoxide derivatives (Kalua et al. 2007). The C-6 aldehydes include saturated aldehyde, hexanal from linoleic acid and the unsaturated aldehyde, cis-3-hexenal from linolenic acid. This unsaturated aldehyde is unstable and undergoes rapid isomerisation to a stable compound, trans-2-hexenal. The C-6 aldehydes formed through the HPL activity can also be further reduced by alcohol dehydrogenase to form the corresponding C-alcohol, like cis-3-hexen-1-01 (Matsui 2006), which is one of the constituents of papaya's volatiles.

Furthermore, alcohol acetate transferase catalyses the formation of acetate esters through acetyl COA derivatives together with alcohol. Acetate ester, esters of alcohols with other fatty acids, as well as the aldehydes and alcohols produced in this pathway are important constituents of papaya fruit which give it a distinct aroma by virtue of the volatiles. Many of the aliphatic esters, alcohols, acids, and carbonyls found in the fruit are derived from the oxidative degradation of linoleic and linolenic acids.

Amino acid metabolism generates aromatic, aliphatic, and branched chain alcohol, acids, carbonyls, and esters that are important to the flavour of papaya (Reineccius 2006). Variations of the free amino acid content in fruits have been known to occur during ripening, corresponding to the period of maximum production of aroma compounds. This is evidence that amino acids are precursors of aroma compounds generated during fruit ripening, and is an important source of volatile compounds contributing to their aroma (Tomas-Barberan et al.1997).

The amino acids present in plants in general are classified under two categories, namely the non-aromatic (absence of benzene ring) amino acids (cysteine, methionine, leucine, isoleucine and valine) and the aromatic amino acids (phenylalanine, tryptophan, tyrosine). Phenylalanine and tyrosine are believed to be the chief precursors of aromatic volatile compounds in plants, synthesized by the shikimic acid pathway. Following the shikimic acid pathway, phenylalnine can enter other two pathways, one of which produces benzyl glucosinolate, the precursor of benzyl isohiocyanate (one of the major compounds in papaya); the other is the cinnamic acid metabolism pathway which produces aromatic alcohols, acids, esters and carbonyls. Aroma compounds can also be synthesized from non-aromatic amino acids precursors (eg. cysteine, methionine, leucine, isoleucineand valine). 
The aromatic amino acids are not naturally present in plants and have to be synthesized by a metabolic pathway, namely the shikimic acid pathway. The shikimic acid pathway converts simple carbohydrate precursors derived from glycolysis and the pentose phosphate pathway to the aromatic amino acids. In the initial steps, D-glucose is phosphorylated. After a series of enzymatic transformations, it is subsequently converted into phenolic compounds, ultimately yielding the active precursor amino acids.

Following the shikimic acid pathway, the other main pathway which phenylalanine enters is the cinnamic acid metabolism (phenyl propanoid pathway). In this pathway, the amino acids are further transformed into aromatic alcohols, acids, esters and carbonyls. Benzaldehyde, 4-methylbenzaldehyde, acetophenone, benzophenone, bdamascone, b-ionone (trace), and benzyl alcohol and phenylacetonitrile (10-50 ppb), which are aromatic compounds found in papaya (Idstein et al. 1985a) are hypothesized to be generated in this manner.

Out of the three aromatic amino acids generated through shikimic pathway, phenylalanine has been stipulated as the chief precursor of aromatic aroma compounds derived from amino acid metabolism (Lamikanra 2002). There are two main pathways which phenylalanine can react to form other compounds. The first of these two main pathways is responsible for forming benzyl glucosinates in the papaya plant.

The synthesis of volatile aroma compounds with non-aromatic amino acids as precursors takes place through a completely different pathway. The pathway follows the citric cycle instead of the shikimic acid pathway. The first step of transamination occurs when glutamic acid is produced from 2-oxoglutarate. The next step is the decarboxylation of 2 oxoacid formed after amino acid transamination. This produces only aliphatic and its branched aroma compounds particularly methyl-branched (aliphatic) alcohols, acids, esters and carbonyls.

As mentioned above, esters are very important contributors to the aroma of papaya (MacLeod \& Pieris 1983; Morales \& Duque 1987). They are formed by the reaction between alcohols and acyl CoA's derived from fatty acid and amino acid metabolism. This reaction is catalyzed by acyl alcohol transferase (AAT) (Sanz et al. 1997; Perez et al. 1996; Ueda et al.1992).

According to a study done by Morales and Duque (1987), the papaya aroma extract's main constituents are carboxylic esters, dominated by the ethyl and butyl esters of the C2-C8 saturated-chain carbocylic acids, with the exception of C5. Saturated normal-chain C4, C6, C7, and C8 methyl esters were also found, as well as other saturated aliphatic and aromatic esters. Some unsaturated esters were also detected: ethyl but-2-enoate, n-butyl but-2-enoate, ethyl oct-2-enoate, and n-butyl oct2 -enoate together with two $\beta$ hydroxy esters, i.e., ethyl-3-hydroxybutyrate and n-butyl 3-hydroxybutyrate. Alcohols, including ethanol, butanol, hexanol, and octanol, were the another group of important components observed in the papaya fruit. These alcohols corresponded to the alcohol part of the identified ester.

There are few flavour constituents that come directly from carbohydrate metabolism. However, terpenes for example, which arise both from carbohydrate and lipid metabolism, also play very important roles in plant's aroma. 
Terpenes are classified by the number of isoprene units (C5). In one particular study by Flath and Forrey (1977), terpenoids constituted $81 \%$ of the total volatiles detected, with the monoterpene alcohol, linalool, representing $68 \%$ of the total emissions. Other terpene hydrocarbons like myrcene, ocimene, limonene, sabinene and neoalloocimeme, and terpene alcohols like aterpineol, nerol, and geraniol also contribute to the major volatiles in papaya (Heidlas et al. 1984; Flath et al. 1990).

Of particular interest are linalool and its pyranoid and furanoid oxides due to their prominence as flavour components of papaya (Schreier \& Winterhalter 1986; Flath et al. 1990). Linalool and its oxides are biosynthesized through geranyl diphospate which produce linalyl cation and linalyl pyrophosphate. Linalyl pyrophosphate are also formed other monoterpenes such as $\alpha$-terpineol, limonene, and pinene.

The amount of free linalool is relatively small in papaya, instead, it often occurs in ripe papaya fruits in a glycosidic bound form, from which it is released through e.g. endogeneous Bglucosidase activity during cell disruption (Heidlas et al. 1984). Linalool glycoside is synthesized by the enzyme glycosyltransferse, and its concentration versus time increased with the maturity of the plant organ. This accumulation is generally coupled with the production of the corresponding free forms.

The degradation of carotenoids, particulary the oxygenated xanthophylls, contributes to the aroma profiles of many fruits and vegetables as well. Trace amounts of the ketone $\beta$-ionone have been identified previously as papaya volatile component (Pino et al. 2003; Flath \& Forrey 1997). The co-oxidative cleavage of carotenoid polyene chains to form ionones and damascenones occurs enzymatically through the action of oxidases including lipoxygenases, peroxidases, and dioxygenases, released during fruit ripening.

\section{Synthesis of Benzyl Glucosinolate}

Glucosinolates are thioglucosides mainly found in the botanical family Cruciferae, although rare occurrence outside this family is also documented. Papaya is one of the best examples of a non-Cruciferae plant which contains benzyl glucosinolates, and hence produces benzyl isothiocyanates among its volatiles, by enzyme actions (MacLeod \& Pieris 1983). Flath and Forrey (1977) confirmed the presence of benzylglucosinolate in papaya fruit based on their discovery of relatively large amounts of both benzylthiocyanate and phenylacetonitrile (another product of benzyl glucosinolate degradation) among the volatile components.

Benzyl glucosinate is a compound that is continually formed during the growth of plant, from seed to fruit. It is present in a high concentration in the young papaya plant, especially in the leaves and roots. As the papaya plant grows, the compound is gradually transported to the fruit (Bennet et al. 1997). From phenylalanine, benzyl glucosinolate is synthesized via three stages: (1) amino acid chain elongation, (2) synthesis of the glucosinolate from the amino acid, and (3) chain modifications. Although it does not contribute much to the flavour of the papaya fruit, it is crucial to the formation of benzyl isothiocyanate (phytochemical containing sulphur and 
nitrogen) of which is a major flavour volatile of the papaya fruit with specific sensory) (Flath \& Forrey 1977; Flath et al. 1990).

Benzyl isothiocyanate has a protective function in the papaya fruit as well. It is produced by the enzymatic hydrolysis of benzyl glucosinolate during fruit injury (Patil et al. 1973). The formation of benzyl isothiocyanate, which are formed from the aglycone by a Lossen re-arrangement involving the migration of the side chain from the oxime carbon to the adjacent nitrogen, is catalysed by myrosinases (Halkier \&and Gershenzon 2006). In fact, even intact papaya fruit releases traces of benzyl isothiocyanate vapour (Patil \& Tang 1974).

\section{FLAVOR CHANGES DURING STORAGE AND PROCESSING}

Like the other soft pulp fruits, papaya is highly perishable \& susceptible to fungal attack during storage. Most of the volatiles formed after storage are mainly due to the mechanical damage sustained by the tissue during preparation such as cutting or fungal attack. The cellular disruption allows enzymes and substrates that are previously sequestered separately within the cells to be able to be interacted, mediated qualitatively and quantitatively and altered, which results in the synthesizing of volatile compounds including 4-methyloctane, tetrahydro-3-furfuryl-furan, 2,4dimethylhexane, benzene-methanol, isopelletierins, 5-6-dimethydecane, cyclohexylazide, undecane, n-tridecane, butyl ketone, 7-tridecanone, 5-9-undecadien2-one \& benzyl tiglate (Mohammed et al. 2001). Schreier \& Winterhalter (1986) has also reported the presence of 6,7-epoxy-linalool, 2,6-dimethyl-1,7-octadiene-3,6-diol, 2,6-dimethyl-3,7-octadiene-2,6-diol, 2,6-dimethyl-3,7-octadiene-2,6-diol, cis and trans-2,6-dimethyl-2,7-octadiene-1,6-diol and 2,6-dimethyl-7-octene-2,3,6-triol as well as four diastereoisomeric epoxy-linalool oxides in their furanoid and pyranoid forms as well.

Although low temperature is used to maintain the freshness of the ripen papaya, continuous changes of the volatile compounds composition were observed during this storage. On the third day of storage, there were major changes in the odour perceived in the ripen papaya (Mohammed et al.2001).

The freshly cut papaya initially has a mixture of flowery, fresh, bergamot-like, fruity, bitter, nutty, almond odour, mainly due to the presence of the dominant odouractive compounds, linalool, which gives flowery and fresh odour reminiscent of lily and benzaldehyde which contributes to bitter nutty and almond odour (Bauer et al. 1997). There are also other trace volatiles such as trans- and cis-linalool oxides, cyclohexane, hexanoic acid and benzenemethanol which contribute to the fruity flavour (Bauer et al. 1997). Furthermore, the presence of cyclic ester, cis-and trans linalool also contribute to the earthy and slightly bergamot-like odour in papaya (Bauer et al. 1997). These flavours perceived from the freshly cut ripen papaya would last for the first two days of storage and change to the different volatiles.

The sweet flowery odour perceived initially was lost on the third day of storage due to a significant decrease of about $50 \%$ of linalool, while benzaldehhyde, linalool cispyranic oxide and cyclohexanebeing vanished (Mohammed et al. 2001). On the other 
hand, benzyl acetate was the dominant aroma volatile at the storage interval and together with un-pleasant earthy flowery odour of trans-linalool and un-pleasant coffee like aroma taking place. The significant increase of butanoic acid present on day 3 , also causes the impartment of dry-flowery lily-like odour, thus intensifies the non pleasant odour of the papaya after 3 days storage.

Upon realizing the undesirable changes of the aroma active compounds during storage of the sliced ripen papaya, it would be advisable that ripe papaya should be consumed immediately after the cutting of the papaya. Otherwise, the papaya should be left without processing which would prevent the formation of non-pleasant volatile compounds due to the cellular disruption.

Papaya puree is the major semi-processed product that is used in juices, nectars, fruits cocktails, jams, jellies and fruit leather (Salunkhe \& Kadam 1995; Somogyi et al. 1996). Commercially, papaya puree is produced by pushing the whole fruit into a pulpier fitted with a 0.033 inch screen. The puree is not heated to inactive the enzymes and even contain pulverized peel and \& seeds. The next step is subjected to subsequent thawing and freezing to dispatch and preserved the puree. As mentioned above, squeezing of the whole fruit into the pulpier will cause the cellular disruption that allows enzymes and substrates to be able to interact, resulting in a similar sweet flowery and fruity odour due to the release of a large amount of linalool, benzaldehyde and other trace compounds. However, using the commercial method on producing papaya puree cannot maintain the sweet flowery and fruity odour, and in turn resulted in the off-flavour perceived in the papaya puree.

The formation of off-flavour was mainly due to the reaction induced by naturally occurring enzymes in the papaya during processing and frozen storage. It is also due to the microbial action in the centre of the puree mass prior to the freezing process and at the periphery of the mass during the thawing process (Chan et al. 1973). Both enzymatic and microbial action causes the formation of butyric, hexanoic, and octanoic acid and their methyl esters. The formation of these free acids which mainly has pungent-rancid odour might contribute to the off-flavour. Furthermore, during the puree process, the content of benzyl isothiocyanate increases significantly higher than the linalool content due to the hydrolysis of glucosinolate by enzyme. This proportion will suppress the sweet flowery odour and intensify the pungent cabbagelike odour as well. To minimize the off-flavour formation, an improved method for processing puree, by acidification to $\mathrm{pH} 3.55$ and thermal in-activation of enzyme, has been developed (Chan et al. 1973).

Aside from being made into puree, as has been mentioned above, papaya can be processed into other products to meet consumer's needs. In processing of all these products, thermal treatment or thermal processing is ubiquitously applied as an essential part, for the purposes of in-activating enzymes, softening of texture, concentration or drying of product, and sterilization. However, the thermal treatment also brings detrimental effects to the product quality, especially with regard to the aroma profile of papaya. The volatile aroma active compounds present in papaya will be inevitably lost to different extent during the thermal treatment.

In a previous summary of the processed papaya products and their processing conditions (Salunkhe \& Kadam 1995; Somogyi et al. 1996), it seems that the 
BIOTROPIA Vol. 20 No. 1, 2013

Table 2. Summary of boiling points of several aroma active compounds in papaya

\begin{tabular}{|c|c|c|c|}
\hline Aroma compounds & $\begin{array}{l}\text { Boiling point } \\
\quad\left({ }^{\mathrm{O} C}\right)\end{array}$ & Aroma compounds & $\begin{array}{l}\text { Boiling point } \\
\left({ }^{\mathrm{O}} \mathrm{C}\right)\end{array}$ \\
\hline Linalool & 198 & Cis-linalool oxide & 188 \\
\hline Benzaldehyde & 178 & Benzyl acetate & 214 \\
\hline Benzyle isothicynate & 243 & $\begin{array}{l}\text { Linalool cis -pyranic } \\
\text { oxide }\end{array}$ & Not available \\
\hline Butonoic acid & 164 & Cyclohexane & 81 \\
\hline 4-Methyloctane & 142 & Gamma hexalactone & 220 \\
\hline Hexanoic acid & 223 & Gamma octalactones & Not available \\
\hline Benzenementhonal & 205 & Delta octalactones & Not available \\
\hline Trans-linalool oxide & Not available & & \\
\hline
\end{tabular}

temperatures involved in the thermal treatments of various processing's are below the boiling points of most aroma active compounds (Table 2). It indicates that during the thermal treatments, cycloxehane will probably be the one which loses most due to its low boiling point, while other compounds will be partly lost due to evaporation. The loss of cyclohexane and other aroma active compounds will lead to the deterioration of olfactory quality of papaya. Therefore, the processed products are often perceived as less sweet or fruity in aroma than the fresh-cut, non-processed fruits.

Based on the boiling point and likelihood of evaporation, the aroma active compounds listed in Table 2 can also be classified roughly into three categories. Cyclohexane which has the lowest boiling point and thus most easily evaporated; and the second group are benzaldehyde, butonoic acid and 4-methyloctane, with the medium boiling point, evaporate at a moderate rate; while other aroma compounds, including linalool, bezyle isothicynate, hexanoic acid, benzenemethonal, cis-linalool oxide, benzyl acetate and gamma-hexalactone, with relatively high boiling points, evaporate at a slow rate.

During the heat treatment, besides loss due to evaporation, some of the aroma active compounds may be oxidized with the presence of oxygen. Among the 15 aroma active compounds identified in papaya, linalool and benzaldehyde, the two major aroma compounds in fresh papaya, are the most susceptible to oxidation. Linalool undergoes autoxidation with $\mathrm{O}_{2}$ to form hydroperoxides, of which 7-hydroperoxy3,7-dimethyl-octa-1,5-diene-3-ol is the most important one (Skold 2006; Backtrop et al.2006) This would result in reduction of linalool and in turn the sweet smell of the papaya aroma in the processed product. Benzadehyde also undergoes autoxidation to perbenzoic acid and converts to benzyl alcohol upon hydrogenation (Bauer et al. 1997). As a result, the bitter almond aroma contributed by benzaldehyde will decrease in the processed papaya product.

To reduce loss of aroma in processed papaya products, irradiation is proposed as an alternative to heat treatment when the purpose is to kill fruit flies, prevent fungal growth or inactivate enzymes. Irradiation is able to achieve the same or better 
outcomes as heat treatment, with much less damage to the sensory qualities of papaya (Moy 1993). However, irradiation cannot replace heat treatment if the product requires be softening or dehydrating. In addition, the resistance to irradiated foods of consumers is still strong in the current context, which poses big challenge to the promotion of irradiation in food products.

\section{CONCLUSIONS}

Papaya is a climacteric fruit that undergoes the ripening process upon harvesting, until the stage where a fully ripened papaya gives fully developed flavours which then is perceived and recognized by human as ripening indication. The flavour of papaya fruit is a result from a complex interactions between sugars, organic acids, minerals, and aroma volatile compounds, which may vary with cultivar and production location. When the papaya fruits are subject to processing, there would be qualitative and quantitative alterations in the overall composition of volatile compounds due to the processing conditions. Volatiles identified in these studies included heterocyclic compounds, terpenoids, aromatic hydrocarbon, alcohol, acids, esters and ketones. A fairly wide range of different types of compounds was identified in different studies. These volatiles are released by harvested intact fruit in small amount per unit time, and some of the reported volatiles are only generated in quantity from non-volatile precursors due to the disruption of fruit tissue. Despite the significant diversity in aroma compounds of papaya fruit, the volatiles in papaya are mainly derived from three major metabolism pathways: the catabolism of fatty acid, amino acid, and carbohydrates. The biosynthesis pathways are usually interlinked, with products from one pathway serving as the precursors for another pathway. These degradation reactions account for many aroma compounds, as they result in the formation of a host of low molecular weight products which has significant sensory properties. Moreover, papaya is one of the best examples of a non- Cruciferae plant which contains benzyl glucosinolates. Although this compound does not contribute much to the flavour of the papaya fruit, it is crucial to the formation of benzyl isothiocyanate (phytochemical containing sulphur and nitrogen with specific sensory), which is a major flavour volatile of the papaya fruit. Benzyl isothiocyanate has a protective function in the papaya fruit.

\section{ACKNOWLEDGMENTS}

This manuscript has been accomplished during the SAME program 2012 funded by DGHE-Ministry of Education and Culture, RI. Thanks should be also addressed to Mr. I Kadek Putra Yudha Prawira for his technical support. 


\section{REFERENCES}

Almora K, Pino JA, Hernandez M, Duarte C, Gonzalez J, Roncal E. 2004. Evaluation of volatiles from ripening papaya (Caricapapaya L., var Maradol roja). Food Chem 86(1):127-30.

Anonymous. 2003. Riset Unggulan Buah Tropis Indonesia. Kompas Edisi Jum'at, 19 Desember 2003. [http://64.203.71.11/kompascetak/0312/19/inspirasi/756234.htm] (accessed on October 20 $0^{\text {th }}, 2007$ ).

Anonymous. 2005. Pengembangan Varietas Papaya. Pusat Kajian Buah-buahan Tropika. Laporan Akhir Rusnas (annual report). Pusat Kajian Buah-buahan Tropika. Bogor; 2005.

Anonymous. 2012. Papaya [http://www.crfg.org/pubs/ff/papaya.html] (accessed on August 28 ${ }^{\text {th }}, 2012$ ).

Arctander S. 1969. Perfume and Flavor Chemicals (Aroma Chemicals) Volume II K-Z. New Jersey: Allured Publishing Corporation.

Bauer K, Garbe D, Surburg H: Common Fragrances and Flavor Materials. 1997. Preparation, Properties and Uses, $3^{\text {rd }}$ edn. New York: Wiley-VCH.

Bennet RN, Kiddle G, Wallsgrove RM. 1997. Biosynthesis of benzylglucosinolate, cyanogenic glucosides and phenylpropanoids in Caricapapaya. Phytochemistry 45(1): 59-66.

Chan Jr HT, Flath RA, Forrey RR, Cavaletto CG, Nakayama TOM, Brekke JE. 1973. Development of off-odors and off-flavors in papaya puree. J Agric Food Chem 21(4): 566-70.

Chay-Prove P, Ross P, O'Hare P, Macleod N, Kernot I, Evans D, Grice K, Vawdrey L, Richards N, Blair A, Astridge D. 2000. Agrilink Series: Your Growing Guide to Better Farming. Papaw Information Kit. Queensland Horticulture Institute and Department of Primary Industries, Qld, Nambour, Qld.

Chehab EW, Perea JV, Gopalan B, Theg S, Dehesh K. 2007. Oxylipin Pathway in Rice and Arabidopsis. J Integr Plant Biol 49(1): 43-51.

Considine DH, Considine GD. 1982. Food and Food Production Encyclopedia. New York: Van Norstand Reinhold Comp.

Devitt LC, Sawbridge T, Holton TA, Mitchelson K, Dietzgen RG. 2006. Discovery of genes associated with fruit ripenings in Carica papaya using expressed sequence tags. Plant Sci 170(2):356-63.

Ettlinger MG, Hodgkins JE. 1956. The mustard oil of papaya seed. J Org Chem. 21:204-5.

Ettlinger MG, Kjaer A. 1968. Sulfur compounds in plants. In: Recent Advances in Phytochemistry. Edited by Mabry TJ, Alston RE, Runeckels VC (eds). New York: Appleton-Century-Crofts 58-144.

Evans EA, Ballen FH. 2012. An overview of Global Papaya Production, Trade, and Consumption [http://edis.ifas.ufl.edu/pdffiles/FE/FE91300.pdf] (accessed October 24 $\left.{ }^{\text {th }}, 2012\right)$.

FAO. 1992. FAO Corporate Document Repository: Papaw. Leaflet No 2-Revised- Papaw. [http://www.fao.org/Wairdocs/X5425E/x5425e02.htm\#TopOfPage] (accessed October 31 ${ }^{\text {th }}, 2012$ )

FAO. 2010. FAOSTAT [http:// faostat.fao.org/site/339/default.aspx] (accessed October 22 $\left.2^{\text {th }}, 2012\right)$.

Flath RA, Forrey RR. 1977. Volatile components of papaya (Carica papaya L., Solo variety). J Agric Food Chem 25(1): 103-9.

Flath RA, Light DM, Jang EB, Mon TR, John JO. 1990. Headspace examination of volatile emissions from ripening papaya (Caricapapaya L., Solo variety). J Agric Food Chem 38(4):1060-3.

Halkier BA, Gershenzon J. 2006. Biology and Biochemistry of Glucosinolates. Annu Rev Plant Biol 57: 303-33.

Heidlas J, Lehr M, Idstein H, Schreier P. 1984. Free and bound terpene compounds in papaya (Carica papaya, L.) fruit pulp. J Agric Food Chem 32(5):1020-1.

Idstein H, Bauer C, Schreier P. 1985․ Volatile acids from tropical fruits: cherimoya (Annona cherimolia Mill.), guava (Psidium guajava L.), mango (Mangifera indica L. var. alphonso), pawpaw (Carica papaya L.). Zeitschrift fur Lebensmittel-Untersuchung und -Forschung 180 (5):394-7.

Idstein H, Keller T, Schreir P. 1985'. Volatile constituents of mountain papaya (Carica candamarcensis, syn. C. pubescens Lenne et Koch) fruit. J Agric Food Chem 33: 663-6. 
Kalua CM, Allen MS, Bedgood Jr DR, Bioshop AG, Prenzler PD, Robards K. 2007. Olive oil volatile compounds, flavour development and quality: A critical review. Food Chem 100: 273-86.

Klein E, Ohloff G. 1962. Die absolute konfiguration des linalools durch verknüpfung mit dem pinansystem. Tetrahedron 18(1): 37-42.

Lamikanra O. 2002. Fresh-cut in Fruits and Vegetables: Science, Technology \& Market. Boca Raton: CRC Press.

Larráyoz P, Addis M, Gauch R, Bosset JO. 2011. Comparison of dynamic headspace and simultaneous distillation extraction techniques used for the analysis of the volatile components in three European PDO ewes milk cheeses. Int Dairy J 11: 911-26.

Lavilla T, Recasens I, Lopez ML, Puy J. 2002. Multivariate analysis of maturity stages, including quality and aroma, in 'Royal Glory' peaches and 'Big Top' nectarines. J Sci Food Agric 82:1842-9.

Macleod AJ, Pieris NM. 1982. Volatile Flavour Components of Mangosteen, Garcinia mangostana. Phytochemistry 21(1):117-9

Macleod AJ, Pieris NM. 1983. Volatile Components of papaya (Carica papaya L.) with Particular Reference to Glucosinolate Products. I Agric Food Chem 31(5):1005-8.

Marostica Jr MR, Pastore GM. 2007. Tropical Fruit Flavour. In: Flavours and Fragrances: Chemistry, Bioprocessing and Sustainability. Edited by Berger RG. Verlag Berlin Heidelberg: Springer 189-202.

Matsui K. 2006. Green leaf volatiles: hydroperoxide Iyase pathway of oxylipin metabolism. Current Opinion in Plant Biology 9:274-280

Mohammed M, Wang Y, Kays SJ. 2001. Change in the volatile chemistry of fresh cut papaya (Carica Papaya L.) during storage. Trop Agric 78(4):268-71.

Morales AL, Duque C. 1987. Aroma constituents of the fruit of mountain papaya (Carica pubescens) from Columbia. J Agric Food Chem 35(4):538-40.

Morton ID, Macleod AJ. 1990. (Eds): Food Flavour: Part C, The Flavour of Fruits. London: Elsevier.

Morton JF. 1987. Fruits of Warm Climates. Winterville: Creative Resource Systems Inc.

Moy JH. 1993. Efficacy of irradiation vs thermal methods as quarantine treatments for tropical fruits. Rad Phy Chem 42:269-12.

Nakasone HY, Paull RE. 1998. Tropical Fruits. UK: Oxon, CAB Intl. 443.

NASS. 2012. USDA National Agriculture Statistics Service 2007 [http://www.nass.usda.gov/Publications/ Ag_Statistics/2007/index.asp] (accessed October $23^{\text {rd }}, 2012$ ).

Organisation for Economic Co-operation and Development [OECD]. 2003. Draft Consensus Document on the Biology of Caricapapaya (L.) (Papaya). Report No. 5 February 2003. France.

Patil SS, Tang C. 1974. Inhibition of ethylene evolution in papaya pulp tissue by benzyl isothiocyanates. Plant Physiol 53(4):585-588.

Patil SS, Tang CS, Hunter JE. 1973. Effect of benzyl ispthiocyanate treatment on the development of post harvests rots in papayas. Plant Dis Rep 57:86-9.

Paul RE, Duarte O. 2011. Papaya, In: Tropical Fruits, Volume 1. Edited by Paul RE and Duarte O. CABI. 11: 291 326.

PCARRD-DOST. 2004. R\&D Status and Directions (2000 and Beyond): Papaya. Payot JA, Anit EA, Dimapilis EM (Volume Eds). Philippine Council For Agriculture, Forestry and Natural Resources Research and Development. Department of Science and Technology. Los Banos: Laguna.

Peng F, Sheng L, Liu B, Tong H, Liu S. 2004. Comparison of different extraction methods: steam distillation, simultaneous distillation and extraction and headspace co-distillation, used for the analysis of the volatile components in aged flue-cured tobacco leaves. J. Chromatogr A 1040(1):1-17.

Perez AG, Sanz C, Rios JJ, Olias JM. 1996. Evolution of Strawberry Alcohol Acyltranferase Activity During Fruit Development and Storage. J Agric Food Chem 44(10):3286-90.

Picha D. 2006. Horticultural crop quality characteristics important in international trade. Acta Horticulturae 712(IV):423-426. [SEMINAR]. 
Pino JA, Almora K, Marbot R. 2003. Volatile components of papaya (Carica papaya L., Maradol variety) fruit. Flavour Frag J 18(6):492-6.

Reineccius G. 2006. Flavour Chemistry and Technology. Boca Raton: Taylor\&Francis.

Rivera-Lopez J, Vazquez-Ortiz FA, Ayala-Zavala JF, Sotelo-Mundo RR, Gonzalez-Aguilar GA. 2005. Cutting shape and storage temperature affect overall quality of fresh-cut papaya cv. 'Maradol'. J Food Sci 70: 482-9.

Sakho M, Chassagne D, Jaus A, Chiarazzo E, Crouzet J. 1998. Enzymatic Maceration: Effect on volatile Components of Mango Pulp. J Food Sci 63(6):975-8.

Salunkhe DK, Kadam SS (Eds.). 1995. Handbook of fruit Science and technology. New York: Marcel Dekker 297-314.

Sanz C, Olias JM, Perez AG. 1997. Aroma biochemistry of fruits and vegetables. In Phytochemistry of Fruit and Vegetables. Edited by Tomas-Baberan FA, Robins RJ (eds). Oxford: Clarendon Press 125-156.

Schreier P, Winterhalter P: Precursors of papaya (Carica Papaya L.) fruit volatiles. 1986. In Biogeneration of Aromas. Edited by Parliament T, Croteau R (eds). Washington DC. American Chem Soc 85-98.

Schreier P, Lehr M, Heidlas J, Idstein H. 1985. Increases aroma from papaya fruit (Caricapapaya L.): An indication of the start of bound terpene volatilization. Z. Lebensm. Unters. Forsch. 180: 297-302.

Schultz TH, Flath RA, Mon TR, Eggling SB, Teranishi R. 1977. Isolation of volatile components from a model system $J$ Agric Food Chem 25 (3): 446-9.

Shashirekha MN, Revathy B, Lingamallu JR, Munusamy R, Vijayalaksmi, Somasundaran R. 2008. Influence of processing conditions on flavour compounds of custards apple (Annona squamosa L.). LWT Food Science and Technology. 41:236-243.

Shiota H. 1991. Volatile components of pawpaw fruit (Asimina triloba Dunal). J Agric Food Chem 39:1631-5.

Sidhu JS. 2006. Tropical Fruits: Guava, Lychee, Papaya. In: Handbook of Fruits and Fruit Processing. Edited by Hui YH, Barta J, Cano MP, Gusek T, Sidhu JS, Sinha NK (eds). Iowa: Blackwell Publishing. p. 597-634.

Skold M, Karlberg AT, Matura M, Borje A. 2006. The fragrance chemical $\beta$-caryophyllene-air oxidation and skin sensitization. Food Chem Toxicol 44(4): 538-45.

Snow NH. 2002. Head-space analysis in modern gas chromatography. Trends in Anal Chem 21(9-10): 608-17.

Somogyi LP, Ramasawamy HS, Hui YH (eds). 1996. Processing Fruits: Science and Technology, Vol. 2. Basel: Technomic Publishing. p. 406-9.

Stumpe M, Carsjens JG, Stenzel I, Göbel C, Lang I, Pawlowski K, Hause B, Feussner I. 2005. Lipid metabolism in arbuscular mycorrhizal roots of Medicago truncatula. Phytochemistry 66:781-91.

Tang C-S. 1971. Benzyl Isothiocynate of Papaya Fruit. Phytochemistry 10:117-21.

Teixeira S, Mendes S, Alves A. 2007. Simultaneous distillation- extraction of high-value volatile compounds from Cistus ladanifer L.[J]. Analytica Chimica Acta 584(2): 439-46.

Tomas-Barberan FA, Robins RJ (eds). 1997. Phytochemistry of Fruit and Vegetables. Edited by Oxford: Clarendon Press; 125-56.

Torres JD, Talens P, Carot JM, Chiralt A, Escriche I. 2007. Volatile profile of mango (Mangifera indica L.), as affected by osmotic dehydration. Food Chem 101:219-28.

TRACE-Molecular Biology database [http://www.bats.ch/trace/?file5=coreforms/ taxonomy.php\&record number=19TT] (accessed October $\left.23^{\text {th }}, 2012\right)$.

Ueda T, Waverczak W, Ward K, Sher N, Ketudat M. 1992. Mutations of the 22- and 27-kD zein promoters affect transactivation by the opaque-2 protein. Plant Cell4: 701-09.

Ulrich D, Wijaya CH. 2010. Volatile patterns of different papaya (Carica papaya L.) Varieties. J Appl Bot Food Qual 83:128-32.

Villegas VN. 1991. Carica papaya L. In: Plant Resources of South-East Asia No. 2: Edible Fruits and Nuts. Edited by Verheij EWM, Coronel RE (eds). Wageningen: Pudoc 108-112. 
Flavour of Papaya (Carica papaya L.) Fruit - C. Hanny Wijaya et al.

Wall MM. 2006. Ascorrbic acid, vitamin A, and mineral composition of banana (Musa sp.) and papaya (Carica papaya) cultivars grown in Hawaii. J Food Composit Anal 19: 434-45.

Winterhalter P, Katzenberger D, Schreier P. 1986. 6,7-Epoxy-linalool and related oxygenated terpenoids from Caricapapaya fruit. Phytochemistry 25: 1347-50

Yilmaz E. 2001. The chemistry of fresh tomato flavor. Turk J Agric 25: 149-55.

Zoe C. 2006. The Fruits of Foreign Trade. Taiwan Review 56 (11): 50-5. 